\title{
Outcomes of Repeated Exposure of the Carp (Cyprinus carpio L.) to Cyanobacteria Extract
}

\author{
M. PALÍKOVÁ ${ }^{1}$, S. NAVRÁTIL ${ }^{1}$, R. KREJČİ ${ }^{2}$, F. ŠTĚRBA ${ }^{3}$, F. TICHÝ ${ }^{4}$, L. KUBALA $^{5}$, \\ B. MARŠ́́LEK ${ }^{6}$, L. BLÁHA ${ }^{7}$
}

1Department of Veterinary Ecology and Environmental Protection, University of Veterinary and

Pharmaceutical Sciences, Brno, Czech Republic, ${ }^{2}$ Department of Fishery and Hydrobiology,

Mendel`s Agricultural and Forestry University, Brno, Czech Republic, ${ }^{3}$ Department of Biology and Wildlife

Diseases, University of Veterinary and Pharmaceutical Sciences, Brno, Czech Republic

${ }^{4}$ Department of Anatomy Histology and Embryology,University of Veterinary and Pharmaceutical Sciences,

Brno, Czech Republic, ${ }^{5}$ Institute of Biophysics, Academy of Sciences of the Czech Republic, Brno, Czech

Republic, ${ }^{6}$ Institute of Botany, Academy of Sciences of the Czech Republic, Brno, Czech Republic,

${ }^{7}$ RECETOX, Masaryk University, Brno, Czech Republic

Received June 27, 2003

Accepted February 11, 2004

\begin{abstract}
Palíková M., S. Navrátil, R. Krejčí, F. Štěrba, F. Tichý, L. Kubala, B. Maršálek, L. Bláha: Outcomes of Repeated Exposure of the Carp (Cyprinus carpio L.) to Cyanobacteria Extract. Acta Vet. Brno 2004, 73: 259-265.

The aim of this study was to examine the influence of a repeated exposure of the carp to the extract of cyanobacteria. We exposed carp embryos and larvae to the extract of cyanobacteria of the cumulative amount of microcystin LR, YR and RR of $1.3 \mu \mathrm{g} \cdot \mathrm{l}^{-1}$ or $13 \mu \mathrm{g} \cdot \mathrm{l}^{-1}$, respectively. One year later we exposed one half of these fish to the second dose of the extract of cyanobacteria of the cumulative amount of microcystins of $13 \mu \mathrm{g} \cdot \mathrm{l}^{-1}$ and the second half to pure water to eliminate the influence of handling stress. The haematological and histological changes were examined. Similar changes of haematological indices were detected both after exposure to the extract and after the handling stress of fish. Especially indices of the red blood cells were characterised by significant increase $(p \leq 0.01$ or $p \leq 0.05)$ of haematocrit value and haemoglobin concentration in groups with long-term exposure (30 days) during the early life stages as well as in control groups. The initial values of white blood cell count were significantly increased $(p \leq$ $0.01)$ in the control group and in the group exposed to the low concentration $\left(1.3 \mu \mathrm{g} \cdot \mathrm{1}^{-1}\right)$ and after short exposure ( 8 days) during the early life stages as compare to other groups. The white blood cell count of these groups significantly decreased $(p \leq 0.01)$ after exposure to both pure water and the extract. Phagocytic activity was significantly decreased $(p \leq 0.01$ or $p \leq 0.05)$ after stress and after exposure to the extract in groups of long term exposure (30 days) during the early life stages in comparison to control and groups of low exposure. Total plasma protein concentration significantly increased $(p \leq 0.01)$ in all groups after exposure to the extract in comparison to the initial values and only in groups of long term exposure during the early life stages and in the control group after the handling stress. The activities of aspartate aminotransferase (AST) and lactate dehydrogenase (LDH) were decreased in groups of long term exposure during the early life stages after the exposure to the extract. Clinical and histological changes were not observed in any group of fish, except for the fatty infiltration of liver with a tendency to focal big droplet dystrophic steatosis in all groups of fish.
\end{abstract}

Erythrocytes, leukocytes, plasma enzymes, total plasma protein, phagocyte activity, early life stages, young fish

Cyanotoxins produced by blue-green algae and released into the water environment represent a serious problem influencing the health status of various organisms. In human and veterinary medicine, cases of health impairment or poisoning due to water blooms of blue-green algae or their toxic products have been reported (Falconer 1989; Carmichael 1992; Rodger et al. 1994).

Address for correspondence:

MVDr. Miroslava Palíková, Ph. D.

Department of Veterinary Ecology and Environmental Protection

University of Veterinary a Pharmaceutical Sciences

Palackého 1-3, 61242 Brno

Czech Republic

Phone: +420541562654

Fax: + 420541562657

E-mail: palikovam@vfu.cz

http:/www.vfu.cz/acta-vet/actavet.htm 
Cyanotoxins cause impairment of the immune system, torpidity and general weakness, vomiting and digestion problems, respiratory and allergic diseases, damage to the liver function and other health problems. Their cancerogenic effects were also documented (Bell and Codd 1994). The influence of cyanotoxins on fish has been studied by a number of authors using clinical, pathomorphological, histological, ultrastructural, haematological and biochemical methods (Bruno et al. 1989; Råbergh et al. 1991; Johnston et al. 1994; Rodger et al. 1994; Tencalla et al. 1994; Carbis et al. 1996a, 1996b, 1997; Bury et al. 1997; Palíková et al. 1998; Vajcová et al. 1998; Navrátil et al. 1998; Kopp and Heteša 2000).

Recently, research into this area has been aimed at the examination of effects of cyanotoxins on early life stages of organisms including fish (Oberemm et al. 1997; Oberemm et al. 1999; Weigand et al. 1999; Fischer and Dietrich 2000). Obere mm et al. (1997) observed mortality and malformations after exposure to various cyanobacterial crude extracts. No effects were observed during the embryonic development. Oberemm et al. (1999) studied the effects of microcystin LR, RR and YR, saxitoxin, anatoxin-a and crude extract of cyanobacteria on the development of fish and amphibians. No acute toxic effects were observed after exposure to pure microcystins. Only in Oncorhynchus mykiss earlier hatching occurred.

The occurrence of higher concentrations of cyanotoxins in the water environment has a seasonal character. The aim of our work was to find out whether there are some differences between extract of cyanobacteria exposed and non-exposed fish during the early life stages after a second exposure.

\section{Materials and Methods}

The early life stages of the carp were exposed during the first year of life for a short ( 8 days) or long (30 days) term exposure to the crude extract of cyanobacteria of the cumulative concentration of $13 \mu \mathrm{g} \cdot \mathrm{l}^{-1}$ (higher concentration) and $1.3 \mu \mathrm{g} \cdot \mathrm{l}^{-1}$ (low concentration), respectively, of microcystins LR, RR and YR. Control group was situated in toxic free water. One year later we exposed the same fish as well as the control fish to the second dose of the crude extract of cyanobacteria of the cumulative concentration of microcystins of $13 \mu \mathrm{g} \cdot 1^{-1}$. Each group was divided into two subgroups, one of which, exposed to the pure water, served as a control (to eliminate the handling stress caused by depletion). The second subgroups were exposed to the repeated exposition of the crude extract of cyanobacteria. The repeated exposition simulates seasonal occurrence of these toxins in water environment. This concentration induced in the first year of the investigation higher mortality and higher occurrence of malformations and histopathological changes in liver after 30-day exposure. According to Bláha and Maršálek (2001), this concentration corresponds with the level of dissolved microcystins $\left(0-45 \mu \mathrm{g} \cdot \mathrm{l}^{-1}\right)$ in drinking water reservoirs in the Czech Republic. The sample of bluegreen algae was collected from the surface water bloom ( 0 to $0.3 \mathrm{~m}$ depth) and concentrated by a plankton net $22 \mu \mathrm{m}$. The sample was stored frozen at $-20^{\circ} \mathrm{C}$. The concentration of microcystins was determined by HPLC according to the method described by Lawton et al. (1994). To obtain the crude extract, the material was ultrasonicated for $7 \mathrm{~min}$ and centrifuged for $20 \mathrm{~min}$ at $5000 \mathrm{rpm}$. Re-extraction was done twice by standard water. The concentration during experiment was maintained by means of changing the bath every $8 \mathrm{~h}$. The initial haematological indices (red blood cell or erythrocyte count - RBC, haemoglobin concentration - Hb, haematocrit value - PCV, mean corpuscular volume - MCV, mean corpuscular haemoglobin - MCH, mean corpuscular haemoglobin concentration - MCHC, white blood cell or leukocyte count - WBC, total plasma protein concentration - TP, activities of alanine aminotransferase - ALT, aspartate aminotransferase - AST, and lactate dehydrogenase - LDH) were determined prior to starting the experiment. The red blood cell indices and the white blood cell count were determined by standard methods according to Svobodová et al. (1986). The total plasma protein concentration and activities of enzymes were determined using commercial Bio-LachemaTest. The haematological indices listed above and also phagocyte activity were determined at the end of the experiment, too. The evaluation of phagocyte activity by luminol enhanced chemiluminiscence was performed using the modified method according to Kubala et al. (1996). The measured data included peak of CL (mV), the time of peak (s) and the integral of CL (mV.s); the integral of CL = the time of peak x peak of CL. The experiment lasted $48 \mathrm{~h}$. Blood for determination of the haematological indices and phagocyte activity was collected by cardiac puncture. Fish were killed, pathologically examined and tissue samples of gills, liver, kidney and spleen were immediately fixed in Bodian solution and processed using standard methods of histology. Tissue sections were stained with haematoxylin-eosin and PAS and examined using light microscopy. Data were statistically evaluated by Student's $t$-test using the STAT PLUS software (Matoušková et al. 1992). 


\section{Results}

Results of the haematological indices are summarized in Tables 1-3.

Table 1

Initial haematological indices (mean $\pm \mathrm{SD}$ ) - before the repetitive exposure

\begin{tabular}{|c|c|c|c|c|c|}
\hline & Control group & $\begin{array}{c}\text { Low } \\
\text { concentration } \\
\text { Short exposure }\end{array}$ & $\begin{array}{c}\text { Higher } \\
\text { concentration } \\
\text { Short exposure }\end{array}$ & $\begin{array}{c}\text { Low } \\
\text { concentration } \\
\text { Long exposure }\end{array}$ & $\begin{array}{c}\text { Higher } \\
\text { concentration } \\
\text { Long exposure }\end{array}$ \\
\hline $\operatorname{RBC}\left(\mathrm{T} . \mathrm{l}^{-1}\right)$ & $1.60 \pm 0.26^{a b}$ & $1.63 \pm 0.20 \mathrm{ab}$ & $1.66 \pm 0.18^{b}$ & $1.55 \pm 0.25 a b$ & $1.42 \pm 0.18^{\mathrm{a}}$ \\
\hline $\operatorname{PCV}\left(1.1^{-1}\right)$ & $0.27 \pm 0.02 \mathrm{AB}$ & $0.29 \pm 0.02^{\mathrm{ABb}}$ & $0.29 \pm 0.02 \mathrm{Bb}$ & $0.28 \pm 0.03 \mathrm{AB}$ & $0.26 \pm 0.02 \mathrm{Aa}$ \\
\hline $\mathrm{Hb}\left(\mathrm{g} . \mathrm{l}^{-1}\right)$ & $71.18 \pm 9.37 \mathrm{~A}$ & $88.84 \pm 13.53^{\mathrm{BCb}}$ & $86.35 \pm 8.51^{\text {в }}$ & $77.70 \pm 8.72 \mathrm{AB}$ & $71.27 \pm 9.49 \mathrm{ACa}$ \\
\hline $\operatorname{MCHC}\left(1.1^{-1}\right)$ & $0.26 \pm 0.02^{\mathrm{Aa}}$ & $0.31 \pm 0.05^{\mathrm{ABb}}$ & $0.29 \pm 0.02^{\mathrm{B}}$ & $0.28 \pm 0.02^{\mathrm{ABb}}$ & $0.27 \pm 0.02^{\mathrm{AB}}$ \\
\hline $\mathrm{MCV}(\mathrm{fl})$ & $175.05 \pm 27.53$ & $180.11 \pm 24.27$ & $177.91 \pm 19.19$ & $179.82 \pm 29.61$ & $185.98 \pm 23.25$ \\
\hline $\mathrm{MCH}(\mathrm{pg})$ & $45.20 \pm 7.56^{\mathrm{a}}$ & $55.38 \pm 11.00^{b}$ & $52.41 \pm 7.39$ ab & $50.93 \pm 8.91 \mathrm{ab}$ & $50.76 \pm 7.94$ ab \\
\hline $\operatorname{ALT}\left(\mu\right.$ kat.1 $\left.{ }^{-1}\right)$ & $0.69 \pm 0.16^{\mathrm{a}}$ & $0.99 \pm 0.27^{b}$ & $1.07 \pm 0.62^{a b}$ & $0.77 \pm 0.23$ ab & $0.75 \pm 0.22^{\mathrm{ab}}$ \\
\hline AST $\left(\mu\right.$ kat..$\left.^{-1}\right)$ & $5.99 \pm 0.97$ & $4.76 \pm 1.86$ & $6.90 \pm 2.66$ & $5.14 \pm 2.10$ & $6.89 \pm 6.25$ \\
\hline LDH $\left(\mu\right.$ kat..$\left.^{-1}\right)$ & $20.02 \pm 4.65$ & $16.80 \pm 7.71$ & $25.63 \pm 10.71$ & $19.34 \pm 10.45$ & $24.61 \pm 21.57$ \\
\hline $\mathrm{TP}\left(\mathrm{g} . \mathrm{l}^{-1}\right)$ & $24.23 \pm 1.05$ & $24.40 \pm 1.34$ & $25.29 \pm 1.40$ & $25.19 \pm 3.30$ & $24.30 \pm 1.62$ \\
\hline WBC $\left(\mathrm{G} . \mathrm{l}^{-1}\right)$ & $39.63 \pm 14.06^{\mathrm{ACb}}$ & $39.38 \pm 9.74^{\mathrm{C}}$ & $23.50 \pm 6.05 \mathrm{ABa}$ & $22.22 \pm 7.87^{\mathrm{B}}$ & $21.86 \pm 7.95^{\mathrm{ABa}}$ \\
\hline $\mathrm{n}$ & 8 & 8 & 8 & 9 & 7 \\
\hline
\end{tabular}

No significant differences were found between the values indicated by the same letters. In case of their total absence in any of the examined parameters, the values are not indicated. Small letters and capitals are used for indicating the significance of differences at the level of $p<0.05$ and $p<0.01$, respectively.

Table 2

Haematological indices of groups exposed to the pure water (mean $\pm \mathrm{SD}$ ) - after the repetitive exposure (elimination of handling stress)

\begin{tabular}{|c|c|c|c|c|c|}
\hline & Control group & $\begin{array}{c}\text { Low } \\
\text { concentration } \\
\text { Short exposure }\end{array}$ & $\begin{array}{c}\text { Higher } \\
\text { concentration } \\
\text { Short exposure }\end{array}$ & $\begin{array}{c}\text { Low } \\
\text { concentration } \\
\text { Long exposure }\end{array}$ & $\begin{array}{c}\text { Higher } \\
\text { concentration } \\
\text { Long exposure }\end{array}$ \\
\hline $\operatorname{RBC}\left(\mathrm{T} .1^{-1}\right)$ & $1.88 \pm 0.17$ & $1.90 \pm 0.25$ & $1.82 \pm 0.34$ & $1.88 \pm 0.16$ & $2.09 \pm 0.30$ \\
\hline PCV $\left(1.1^{-1}\right)$ & $0.32 \pm 0.01^{\mathrm{B}}$ & $0.29 \pm 0.02^{\mathrm{A}}$ & $0.29 \pm 0.03^{\mathrm{A}}$ & $0.32 \pm 0.02^{\mathrm{B}}$ & $0.33 \pm 0.02^{\text {в }}$ \\
\hline $\mathrm{Hb}\left(\mathrm{g} . \mathrm{l}^{-1}\right)$ & $89.49 \pm 6.25$ Аа & $80.55 \pm 6.33 \mathrm{Ab}$ & $83.38 \pm 6.88^{\text {Aab }}$ & $94.48 \pm 7.23^{\mathrm{AB}}$ & $100.73 \pm 7.53^{\mathrm{B}}$ \\
\hline $\operatorname{MCHC}\left(1.1^{-1}\right)$ & $0.28 \pm 0.02$ & $0.28 \pm 0.01$ & $0.29 \pm 0.01$ & $0.29 \pm 0.02$ & $0.30 \pm 0.01$ \\
\hline MCV (fl) & $170.39 \pm 14.63$ & $154.38 \pm 14.34$ & $163.76 \pm 33.84$ & $171.78 \pm 13.19$ & $161.44 \pm 17.17$ \\
\hline $\mathrm{MCH}(\mathrm{pg})$ & $47.90 \pm 5.46 \mathrm{ABb}$ & $42.72 \pm 3.75 \mathrm{Aa}$ & $47.97 \pm 10.19^{\mathrm{ABab}}$ & $50.31 \pm 2.61^{\mathrm{Bab}}$ & $48.85 \pm 5.80^{\mathrm{ABb}}$ \\
\hline $\operatorname{ALT}\left(\mu\right.$ kat. $\left.^{-1}{ }^{-1}\right)$ & $0.70 \pm 0.18$ & $0.61 \pm 0.12$ & $0.61 \pm 0.16$ & $0.69 \pm 0.22$ & $0.60 \pm 0.09$ \\
\hline AST $\left(\mu\right.$ kat.l. $\left.^{-1}\right)$ & $6.29 \pm 2.22^{b}$ & $5.68 \pm 3.09 \mathrm{ab}$ & $5.55 \pm 1.73 \mathrm{ab}$ & $4.80 \pm 2.48 \mathrm{ab}$ & $4.24 \pm 1.39^{a}$ \\
\hline LDH ( $\left(\mu\right.$ kat. $\left.^{-1}\right)$ & $18.31 \pm 9.05$ & $19.97 \pm 14.66$ & $16.75 \pm 6.97$ & $11.83 \pm 9.02$ & $13.02 \pm 10.03$ \\
\hline TP $\left(\right.$ g. $\left.1^{-1}\right)$ & $27.50 \pm 1.70 \mathrm{~A}$ & $26.68 \pm 2.92 \mathrm{~A}$ & $26.71 \pm 1.89 \mathrm{~A}$ & $32.85 \pm 2.65$ B & $31.76 \pm 1.18^{\text {в }}$ \\
\hline WBC $\left(\right.$ G. $\left.^{-1}\right)$ & $16.75 \pm 5.31 \mathrm{ABab}$ & $12.50 \pm 3.30 \mathrm{Aa}$ & $19.00 \pm 4.78^{\mathrm{Bab}}$ & $18.88 \pm 7.49$ ABab & $21.38 \pm 9.80 \mathrm{ABb}$ \\
\hline $\begin{array}{l}\text { CL-integral } \\
\text { x1000 (mV.s) }\end{array}$ & $817 \pm 360^{\text {Bab }}$ & $509 \pm 4239 \mathrm{ABb}$ & $566 \pm 347 \mathrm{ABb}$ & $241 \pm 137 \mathrm{Aa}$ & $379 \pm 190$ Aab \\
\hline $\mathrm{n}$ & 8 & 8 & 8 & 8 & 8 \\
\hline
\end{tabular}

No significant differences were found between the values indicated by the same letters. In case of their total absence in any of the examined parameters, the values are not indicated. Small letters and capitals are used for indicating the significance of differences at the level of $p<0.05$ and $p<0.01$, respectively.

Changes of the haematological indices after exposure to the extract of cyanobacteria were similar to those after the stress of handling of fish. Especially the changes of the indices of red blood cells were characterised by a significant increase $(p \leq 0.01)$ of 
Table 3

Haematological indices of groups exposed to the extract of cyanobacteria $($ mean $\pm \mathrm{SD})$ - after the repetitive exposure

\begin{tabular}{|c|c|c|c|c|c|}
\hline & Control group & $\begin{array}{c}\text { Low } \\
\text { concentration } \\
\text { Short exposure }\end{array}$ & $\begin{array}{c}\text { Higher } \\
\text { concentration } \\
\text { Short exposure }\end{array}$ & $\begin{array}{c}\text { Low } \\
\text { concentration } \\
\text { Long exposure }\end{array}$ & $\begin{array}{c}\text { Higher } \\
\text { concentration } \\
\text { Long exposure }\end{array}$ \\
\hline $\operatorname{RBC}\left(\mathrm{T} \cdot \mathrm{l}^{-1}\right)$ & $1.79 \pm 0.12$ & $1.74 \pm 0.18$ & $1.75 \pm 0.21$ & $1.98 \pm 0.38$ & $1.78 \pm 0.26$ \\
\hline $\operatorname{PCV}\left(1 \cdot 1^{-1}\right)$ & $0.31 \pm 0.01 \mathrm{Aa}$ & $0.28 \pm 0.04 \mathrm{Aa}$ & $0.30 \pm 0.01 \mathrm{Aa}$ & $0.33 \pm 0.01 \mathrm{Bb}$ & $0.31 \pm 0.03 \mathrm{ABb}$ \\
\hline $\mathrm{Hb}\left(\mathrm{g} \cdot \mathrm{l}^{-1}\right)$ & $91.44 \pm 6.43 \mathrm{bc}$ & $82.63 \pm 7.53 \mathrm{a}$ & $85.35 \pm 5.85 \mathrm{ab}$ & $93.14 \pm 8.11^{\mathrm{c}}$ & $92.58 \pm 8.59 \mathrm{bc}$ \\
\hline $\operatorname{MCHC}\left(1 \cdot 1^{-1}\right)$ & $0.30 \pm 0.02$ & $0.30 \pm 0.05$ & $0.28 \pm 0.01$ & $0.28 \pm 0.02$ & $0.30 \pm 0.01$ \\
\hline MCV (fl) & $170.87 \pm 7.55$ & $162.39 \pm 30.06$ & $176.13 \pm 29.76$ & $169.73 \pm 26.69$ & $177.10 \pm 17.01$ \\
\hline $\mathrm{MCH}(\mathrm{pg})$ & $51.11 \pm 3.67$ & $47.92 \pm 5.68$ & $49.67 \pm 9.63$ & $48.06 \pm 7.20$ & $52.57 \pm 5.41$ \\
\hline $\operatorname{ALT}\left(\mu \mathrm{kat} \cdot 1^{-1}\right)$ & $0.77 \pm 0.31$ & $0.63 \pm 0.27$ & $0.54 \pm 0.07$ & $0.58 \pm 0.14$ & $0.74 \pm 0.29$ \\
\hline $\operatorname{AST}\left(\mu \mathrm{kat} \cdot 1^{-1}\right)$ & $7.92 \pm 3.56^{\mathrm{Bbc}}$ & $6.15 \pm 1.32^{\mathrm{B}}$ & $5.43 \pm 2.38 \mathrm{ABbd}$ & $3.94 \pm 0.94 \mathrm{Aad}$ & $3.20 \pm 1.34$ Aac \\
\hline LDH $\left(\mu \mathrm{kat} \cdot \mathrm{l}^{-1}\right)$ & $26.48 \pm 18.15^{\mathrm{Abbc}}$ & $20.04 \pm 9.17 \mathrm{Bb}$ & $18.07 \pm 12.89 \mathrm{ABabc}$ & $11.32 \pm 5.64 \mathrm{ABac}$ & $7.23 \pm 5.44$ Аа \\
\hline $\mathrm{TP}\left(\mathrm{g} \cdot \mathrm{l}^{-1}\right)$ & $32.08 \pm 1.14^{\mathrm{B}}$ & $29.20 \pm 1.71 \mathrm{~A}$ & $29.26 \pm 2.10^{\mathrm{A}}$ & $30.46 \pm 0.89 \mathrm{~A}$ & $30.56 \pm 1.79 \mathrm{AB}$ \\
\hline WBC $\left(G \cdot 1^{-1}\right)$ & $19.75 \pm 5.28$ & $17.50 \pm 5.50$ & $15.63 \pm 5.66$ & $18.63 \pm 2.92$ & $19.25 \pm 5.90$ \\
\hline $\begin{array}{l}\text { CL-integral } \\
\times 1000(\mathrm{mV} . \mathrm{s})\end{array}$ & $733 \pm 290 \mathrm{BCb}$ & $701 \pm 175^{\mathrm{BCb}}$ & $1073 \pm 520 \mathrm{Cab}$ & $413 \pm 295 \mathrm{ABa}$ & $355 \pm 171$ Aab \\
\hline $\mathrm{n}$ & 8 & 8 & 8 & 8 & 8 \\
\hline
\end{tabular}

No significant differences were found between the values indicated by the same letters. In case of their total absence in any of the examined parameters, the values are not indicated. Small letters and capitals are used for indicating the significance of differences at the level of $p<0.05$ and $p<0.01$, respectively.

haematocrit value and haemoglobin concentration in groups of long term exposure during the early life stages and in control groups in comparison with initial indices. The initial values of the white blood cell count were significantly increased in the control group ( $p \leq$ $0.01)$ and in the group of low concentration of extract and a short exposure during the early life stages $(p \leq 0.05)$ in comparison with other groups. The white blood cell count of these groups significantly decreased $(p \leq 0.01)$ after the application of the extract of cyanobacteria and after pure water, too. The phagocyte activity is presented as an integral of chemiluminiscence (CL) only, because the statistical significance is maximum in this parameter. The integral of CL was significantly decreased after the stress and after the exposure to the extract of cyanobacteria at groups with the long-term exposure during the early life stages. The total plasma protein concentration was significantly increased ( $p \leq$ 0.01 ) in groups with long term exposure during the early life stages due to stress and in the control group after the exposure to the extract. In comparison to the initial values, the total plasma protein concentration significantly increased $(p \leq 0.01)$ in all groups after the exposure to the extract and only in groups of long term exposure during the early life stages and in the control group after the stress. The activities of AST and LDH were significantly decreased in groups with long term exposure during the early life stages after the exposure to the extract as compare to other groups. In comparison to initial values, in all groups, except control and group with low concentration of extract and with short-term exposure during the early life stages, the AST and LDH activities decreased after exposure of extract and after stress. Mainly in the control after application of the extract these activities increased, but not significantly.

Clinical and histological changes were not observed, except for the liver fatty infiltration with a tendency to focal big droplet dystrophic steatosis in all groups of fish. The described changes of liver tissue were more pronounced in groups exposed to the extract during the early life stages. 


\section{Discussion}

Our results show that the used concentration of the second exposure was low to cause histopathological changes of gills, liver, kidney and spleen and increasing of the enzymes activity. Fatty infiltration of liver commonly occurs as a result of feeding, but it can also occur in toxic conditions or vitamin deficiencies (Roberts and Rodger 2001). In our trial, it could be interpreted as a result of feeding pelleted feed with a high content of fat, but toxic influence cannot be excluded. A very important result was the decrease of the activities of AST and LDH in groups with long-term exposure to the extract during the early life stages. Numerous papers (Carbis et al. 1994; Råberg et al. 1991; Navrátil et al. 1998; Vajcová et al. 1998) report the possible effect of cyanotoxins on fish causing the increase of enzyme activities. Our finding evokes a question of certain tolerance and adaptation of the organism due to the increased activity of detoxication. This idea supports the fact that these enzyme activities increased in the control and in the group with low doses and short-term exposure in early life stages after administration of extract. Navrátil et al. (1998) describes changes in the indices of red blood cells after oral administration of biomass of blue green algae. We detected the increase of these parameters, but no pathomorphological changes were found. These changes were influenced by the dose and time after treatment and they have often shown various trends. Almost character of these changes consisted in the decrease of $\mathrm{RBC}$ and $\mathrm{Hb}$. These trends may be explained by pathomorphological findings (haemorrhages in the skin, eyes, hepatopancreas and in swim bladder). The second exposure caused no signs of damage or mortality of fish. Phagocyte activity was significantly decreased after the stress and after the exposure to the extract of cyanobacteria in groups with the long-term exposure during the early life stages. The decrease of phagocyte activity due to the effect of microcystin LR was described by Palíková et al. (1998). These authors describe the significant decrease of phagocyte activity in common and silver carp after oral administration of biomass of blue-green algae with volume of microcystin LR 3 and $300 \mu \mathrm{g}$ per $\mathrm{kg}$ of body mass.

In summary we can say that the used concentration of the second exposure was low to cause clinical and histopathological changes. Chosen concentration of the extract acted in a similar way as the stress of handling. Fish exposed to the extract for a long term during their early periods of development reacted by changes of the red blood cell indices (increase of haematocrit value and haemoglobin concentration, in particular) and changes of the white blood cell indices (decrease of phagocyte activity). Fish not exposed to the extract and fish exposed for a short-term to the low concentration of the extract reacted by decrease of the white blood cell count without the decrease of phagocyte activity.

\section{Vliv opakované expozice extraktu sinic na kapra (Cyprinus carpio L.)}

Cílem našeho sledování bylo zjistit vliv opakované expozice extraktu sinic na kapra. Kapř́i embrya a larvy jsme vystavili působení extraktu sinic s kumulativním obsahem mikrocystinů LR, YR a RR 1,3 $\mu \mathrm{g} \cdot \mathrm{l}^{-1}$ nebo $13 \mu \mathrm{g} \cdot \mathrm{l}^{-1}$. Po roce jsme polovinu těchto ryb vystavili působení druhé dávky extraktu sinic s kumulativním obsahem mikrocystinů 13 $\mu \mathrm{g} \cdot \mathrm{l}^{-1}$ a druhou polovinu ryb jsme pouze přelovovali v čisté vodě, abychom vyloučili vliv manipulačního stresu. Zjištovali jsme hematologické a histologické změny. Podobné změny hematologických ukazatelů jsme zaznamenali vlivem manipulačního stresu i po expozici ryb extraktu sinic. U skupin s dlouhou expozicí (30 dní) v raném vývoji a u kontrolních skupin došlo k průkaznému nárůstu hematokritové hodnoty a koncentrace hemoglobinu. Počáteční hodnoty počtu leukocytů byly signifikantně vyšší $(p \leq 0.01)$ u kontrolní skupiny a u skupiny vystavené v raných vývojových stádiích krátkodobé expozici (8 dní) a nízké koncentraci $\left(1,3 \mu \mathrm{g} \cdot \mathrm{l}^{-1}\right) \mathrm{v}$ porovnání s ostatními skupinami. 
U těchto skupin rovněž došlo jak vlivem manipulačního stresu, tak po aplikaci extraktu $\mathrm{k}$ signifikantnímu poklesu počtu leukocytů $(p \leq 0.01)$. Fagocytární aktivita signifikantně poklesla jak v důsledku stresu, tak i po expozici extraktu ve skupinách vystavených v raných stádiích vývoje dlouhodobé expozici (30 dní) v porovnání s kontrolní skupinou a se skupinami s krátkou expozicí v raných stádiích vývoje. Koncentrace celkové bílkoviny krevní plasmy se po opakované expozici extraktu signifikantně zvýšila ( $p \leq$ 0.01) u všech skupin oproti vstupním hodnotám a vlivem stresu pouze u skupin vystavených v raných vývojových stádiích dlouhodobé expozici a u kontrolní skupiny. Aktivity aspartát-aminotransferázy (AST) a laktát-dehydrogenázy (LDH) se po aplikaci extraktu snížily u skupin dlouhodobě vystavených extraktu sinic v raných stádiích. Klinické a histologické změny jsme s výjimkou tukové infiltrace jater s tendencí k velkokapénkové dystrofické steatóze, zjištované ve všech skupinách, nepozorovali.

\section{Acknowledgements}

Supported by the Internal Grant Agency of the University of Veterinary and Pharmaceutical Sciences Brno, Czech Republic (Project No. 11/2000/FVHE), the Grant Agency of the Czech Republic (Project No. 524/01/P027) and the association Flos-aquae.

\section{References}

BELL, SG, CODD, GA 1994: Cyanobacterial toxins and human health. Rev Medic Microbiol 5: 256-264

BLÁHA, L, MARŠÁLEK, B 2001: Dissolved microcystins in Raw and treated drinking water in the Czech republic. In: Chorus I. Ed. Cyanobacterial Toxins, Springer Verlag, Berlin, pp. 212-217

BRUNO, DW, DEAR, G, SEATON, DD 1989: Mortality associated with phytoplankton blooms among farmed Atlantic salmon, Salmo salar, L., in Scotland. Aquaculture 78: 217-222

BURY, NR, McGEER, JC, EDDY, FB, CODD, GA 1997: Liver damage in brown trout, Salmo trutta L., and rainbow trout, Oncorhynchus mykiss (Walbaum), following administration of cyanobacteria hepatotoxin microcystin-LR via the dorsal aorta. J Fish Dis 20: 209-215

CARBIS, CR, SIMONS, JA, MITCHELL, GF, ANDERSON, JW, McCAULEY, I 1994: A biochemical profile for predicting the chronic exposure of sheep to Microcystis aeruginosa, an hepatotoxic species of blue-green alga. Res Vet Sci 57: 310-316

CARBIS, CR, MITCHELL, GF, ANDERSON, JW, McCAULEY, I 1996a: The effect of microcystin on the serum biochemistry of carp, Cyprinus carpio, L., when toxins are administered by gavage, immersion and intraperitoneal routes. J Fish Dis 19: 151-159

CARBIS, CR, RAWLIN, GT, MITCHELL, GF, ANDERSON, JW, McCAULEY, I 1996b: The histopathology of carp, Cyprinus carpio, L., exposed to microcystins by gavage, immersion and intraperitoneal administration. J Fish Dis 19: 199-207

CARBIS, CR, RAWLIN, GT, GRANT, P, MITCHELL, GF, ANDERSON, JW, McCAULEY, I 1997: The study of feral carp, Cyprinus carpio, L., exposed to Microcystis aeruginosa at Lake Mokoan, Australia, and possible implications for fish health. J Fish Dis 20: 81-91

CARMICHAEL, WW 1992: Cyanobacteria secondary metabolites - the cyanotoxins. A review. J Appl Bacteriol 72: 445-459

FALCONER, RI 1989: Effects on human health of some toxic cyanobacteria. Toxic Assess 4: 175-184

FISCHER, WJ, DIETRICH, DR 2000: Toxicity of the cyanobacterial cyclic heptapeptide toxins microcystinLR and -RR in early life-stages of the African clawed frog (Xenopus laevis). Aquat Toxicol 49: 189-198

JOHNSTON, NAL, CAMPAGNA, VS, HAWKINS, PR, BANENS, RJ 1994: Response of the eastern rainbowfish (Melanotaenia duboulayi) to toxic Microcystis aeruginosa. Aust J Mar Freshwater Res 45: 917-23

KOPP, R, HETEŠA, J 2000: Changes of haematological indices of juvenile carp (Cyprinus carpio L.) under the influence of natural populations of cyanobacterial water blooms. Acta Vet Brno 69: 131-37

KUBALA, L, LOJEK, A, ČÍŽ, M, VONDRÁČEK, J, DUŠKOVÁ, M, SLAVÍKOVÁ, H 1996: Determination of phagocyte activity in whole blood of carp (Cyprinus carpio) by luminol-enhanced chemiluminiscence. Vet Med-Czech 41: 323-327

LAWTON, LA, EDWARDS, C, CODD, GA 1994: Extraction and high-performance liquid-chromatographic method for the determination of microcystins in raw and treated waters. Analyst 119: 1525-1530

MATOUŠKOVÁ, O, CHALUPA, J, CÍGLER, M, HRUŠKA, K 1992: Statistic system STAT PLUS, version 1.01. Book of reference. Veterinary Research Institute, Brno, $168 \mathrm{p}$.

NAVRÁTIL S, PALÍKOVÁ M, VAJCOVÁ V 1998: The effects of pure microcystin LR and biomass of bluegreen algae on blood indices of carp (Cyprinus carpio L.). Acta Vet Brno 67: 273-279 
OBEREMM, A, FASTNER, J, STEINBERG, CEW 1997: Effects of microcystin LR and cyanobacterial crude extracts on embryo-larval development of zebrafish (Danio rerio). Water Res 31: 2918-2921

OBEREMM, A, BECKER, J, CODD, GA, STEINBERG, C 1999: Effects of cyanobacterial toxins and aqueous crude extracts of cyanobacteria on the development of fish and amphibians. Environ Toxicol 14: 77-87

PALÍKOVÁ, M, KOVÁŘ Ů, F, NAVRÁTIL, S, KUBALA, L, PEŠÁK, S, VAJCOVÁ, V 1998: The effects of pure microcystin LR and biomass of blue-green algae on selected immunological indices of carp (Cyprinus carpio L.) and silver carp (Hypophthalmichthys molitrix Val.). Acta Vet Brno 67: 265-272

RÅBERGH, CMI, BYLUND, G, ERIKSSON, JE 1991: Histopathological effects of microcystin LR, a cyclic polypeptide toxin from the cyanobacterium (blue-green alga) Microcystis aeruginosa on common carp (Cyprinus carpio L.). Aquat Toxicol 20: 131-146

ROBERTS, RJ, RODGER, HD 2001: The pathophysiology and systematic pathology of teleosts. In: ROBERTS RJ (Ed): Fish pathology. W. B. Saunders, London - Toronto, pp. 55-132

RODGER, HD, TURBULL, T, EDWARDS, C, CODD, GA 1994: Cyanobacterial (blue-green algal) bloom associated pathology in brown trout, Salmo trutta L., in Loch Leven, Scotland. J Fish Dis 17: 177-181

SVOBODOVÁ, Z, PRAVDA, D, PALÁČKOVÁ, J 1986: Unified methods of fish haematological investigations. Edition of methods, No. 22, Research Institute of Fish Culture and Hydrobiology, Vodňany, 36 pp. (In Czech)

TENCALLA, FG, DIETRICH, DR, SCHLATTER, CH 1994: Toxicity of Microcystis aeruginosa peptide toxin to yearling rainbow trout (Oncorhynchus mykiss). Aquat Toxicol 30: 214-224

VAJCOVÁ, V, NAVRÁTIL, S, PALÍKOVÁ, M 1998: The effect of intraperitoneally applied pure microcystin LR on haematological, biochemical and morphological indices of silver carp (Hypophthalmichthys molitrix Val.). Acta Vet Brno 67: 281-287

WIEGAND, C, PFLUGMACHER, S, OBEREMM, A, MEEMS, N, BEATTIE, KA, STEINBERG, C, CODD, DA: Uptake and effects of Microcystin-LR on detoxication enzymes of early life stages of the zebra fish (Danio rerio). Environ Toxicol 14: 89-95 